\title{
IS THE INTERPLAY OF LOCALISATION AND STANDARDISATION OF HRM PRACTICES THE STRATEGIC OPTION FOR WESTERN SUBSIDIARIES IN GHANA?
}

\author{
Theophilus Azungah \\ Bolgatanga Polytechnic, Republic of Ghana \\ tazungah@yahoo.com
}

\begin{abstract}
As part of sub-Saharan Africa, Ghana has not missed the opportunity to attract considerable investment from Western multinational enterprises (MNEs) due to its rich natural resources and potential for growth, yet presents specific challenges to these enterprises particularly when seeking to transfer their human resource management (HRM) practices to their operations in Ghana. A review of the International Business (IB) literature reveals a serious gap in the interplay of standardisation and localisation of HRM practices in Western subsidiaries in Ghana despite their growing presence. Using institutional theory as the theoretical foundation for this research, I examine how the normative institutional distance between Ghana and Western countries influence the standardisation and localisation of HRM practices of western subsidiaries. This research employs a qualitative multiple case study approach using semi-structured interviews with employees and managers in purposefully selected Western subsidiaries in Ghana and triangulate interview data with document analysis. This study contributes to the IB scholarly conversation on whether standardisation and localisation of HRM practices can be implementedconcurrently. It explains methodologically how and why this occurs. The study also offers practical implications as to which practices to transfer and which not.
\end{abstract}

Keywords : MNEs, Africa, Ghana, HRM, localisation, standardisation, interplay 


\subsection{Introduction}

Notwithstanding Africa's growing economic importance, compared to developing economies in Eastern Europe, Asia, and Latin America, academic research on Africa is relatively weak (Bloom, Canning, and Chan, 2006). It is suggested that the extant literature in IB on Africa has largely focused on issues of subsidiaries of multinational enterprises (MNEs) from South Africa (e.g. Adams, Nyuur, Ellis, \& Debrah, 2016; Davis \& Luiz, 2015; Wood, 2015); China and India (e.g. Akorsu \& Cooke, 2011) and China (e.g. Kamoche \& Siebers, 2015; Siebers, Kamoche, \& Li, 2015). These studies include analysis of transfer of human resource management (HRM) practices, employment standards, industrial relations and employment conditions of MNEs, use of expatriate workers for even unskilled jobs instead of developing local employees (Cooke, Wood, \& Horwitz, 2015; Horwitz, 2012; Lee, 2009; Jackson, 2014; Sautman \& Hairong, 2007).Regardless of the fact thatresearch on HRM and management in Africa is growing (Aryee, 2004; Budhwar \&Debrah, 2001; Jackson, 2004; Kamoche, Siebers, Mamman, \& Newenham-Kahindi, 2015), "there is a significant paucity of empirical research on HRM [...] in European and US firms" (Horwitz, 2015). Horwitz (2015) further emphasised that besides the paucity of research, there is shallowness of literature of western MNEs in Africa.

Against this background, this paper attempts to address the following questions: (i) does the Ghanaian institu-tional context influence standardisation and localisation of recruitment and selection; training and development practices of subsidiaries of Western MNEs in Ghana? (ii) How do western MNEs manage the interplay between localisation and standardisation of recruitment and selection; training and develop ment practices in their subsidia-ries in Ghana?

There are serious gaps in our understanding of the interplay between localisation and standardisation of HRM practices of western subsidiaries in Ghana. This research aims to fill this gap and to enhance understanding of the standardisation and localisation of HRM practices in the Ghanaian context. To my knowledge, this study is the first of its kind to carry out an extensive and indepth empirical investigation on transfer of HRM practices by western MNEs to their subsidiaries in Ghana.

Our theoretical foundation is institutional theory based on normative distance between the home country of western MNEs and Ghana and how it 
influences localisation and standardisation of HRM practices. According to Kostova and Zaheer (1999), normative institutional distance refers to the differences and similarities between the normative institutional environments (beliefs, norms, social values) of the MNE home country and the host context. They maintain that the larger the institutional distance between the host and parent country of the MNE, the more difficult it is to establish legitimacy or to transfer a practice from the parent company of an MNE to a subsidiary (Kostova, 1999). Gaining legitimacy both within an MNE and externally in a host country is crucial for successful operations (Xu, Pan, \& Beamish, 2004). Legitimacy is the process of the MNE gaining acceptance and approval to operate in its environment by the legitimating authorities in the host countries (Kostova \& Zaheer, 1999). Ghana's institutional specificities and the crucial challenges they (institutional specificities) pose to western subsidiaries are discussed next.

\subsection{Ghana's Institutional spe- cificities and Western MNE challenges}

I now describe in detail some of the cultural and institutional specificities of Africa and specifically the Ghanaian context that might pose as serious challenges to Western MNEs. It is important to emphasise that the cultural and institutional contexts of African countries are not homogenous (Adeleye, 2011; Ellis et al., 2015; Osabutey et al., 2015). Similarly, differences in some HRM practices exist among different African countries (Jackson, 2004). Horwitz (2014) points out that the universal assumption of homogeneity of countries in the continentis likely to obscure the corporality of the diversities.

In Africa formal institutions such as courts and other legal mechanisms have high costs and are therefore seldom utilized and as a result, 'informal arbitration often becomes a default option in alleviating uncertainty and resolving disputes' (Peng, 2014: 13). In their study of 12 small and medium sized enterprises (SMEs) exporting from Ghana to other West African countries, Amoako and Lyon (2014) observe that the legal systems of these countries (Ghana and other West African countries) are perceived to be corrupt, expensive and a waste of time due to the long processes entailed in settling disputes. As a result, recourse to the court system is avoided and certain culturally specific institutions such as chiefs and religious leaders are used in the settlement of disputes. Further to this, Acquaah (2007: 1240) 
observes that in Ghana, as in many other African countries, 'there are two parallel political systems and authorities: (1) the formal political system of the modern nation state, and (2) traditional political systems that pre-date the modern nation state.' Key authority in many African countries is in the hands of chiefs. A gerontocracy which comprises of the chief and his elder kinsmen tends to constitute the law courts in the community, and the paramount chief performs the role of a chief justice(Zoogah, Peng, \& Woldu, 2015). Chiefs help to instil discipline and to improve the legitimacy and enforceability of rule of law and property rights' (Dia, 1996: 106). This is not surprising bearing in mind that about 80 percent of land is customarily owned by families, clans and traditional authorities, such as chiefs, in Ghana (Kasanga \& Kotey, 2001).

Acquaah (2007: 1240) points out that 'in Africa, community leaders such as local chiefs and kings and religious leaders are very influential in garnering resources and providing access to valuable information and knowledge to businesses.' In fact, the national constitutions of some countries, such as Ghana and Uganda, recognize ethnic institutions in the settlement of property rights, disputes, and enforcement of customary law (Michalopoulos\& Papaioannou, 2013).
I have selected Ghana as the focus of this study because it is the sixth-largest recipient of FDI in Africa and second in West Africa (Ernest \& Young, 2015; UNCTAD, 2013). The growth in FDI is significant for this study because of the associated expansion of employment opportunities (GIPC, 2016) and the probable transfer of HRM practices. The total number of new projects registered in 2015 was 170 with a total estimated value of US\$2.68 billion (GIPC, 2015). These enterprises were expected to create 14,948 jobs with 13,534 jobs for Ghanaians and the remaining 1,414 for expatriates. GIPC also recorded 136 new projects in 2016 with a total of 8,103 jobs expected to be created. The main investor countries in Ghana include USA, Britain, France, Canada, South Africa, Brazil, Norway, India and China (GIPC, 2015; 2016). According to Sutton and Kpentey (2012: 1), "Ghana has been one of Africa's fastest growing economies over the past decade." Due to the stable institutional environment and the growth of FDI, there has been a corresponding increase in employment (GIPC, 2013).

When MNEs endeavour to transfer HRM practices to their foreign subsidiaries, they typically achieve either standardization or localization of practices. Smith (2008: 319) observes that 'there is little doubt that effective management is 
a blend of universal processes and specific local issues. The question that remains open for debate is the relative preponderance of the universal and the local.' The prevalence of universal or local issues can result from a dilemma between satisfying the interests of the parent company or those of local stakeholders (Kostova \& Roth, 2002) and this leads to decisions about the degree of standardization or localization that occurs. In this paper I explore how Ghana's cultural and institutional context influence HRM practices of western MNE subsidiaries and the extent to which these practices reflect standardization or localization. I examine where a dual approach may result from interplay of the local context and parent country practices. In so doing I extend the scholarly conversation on transfer of HRM practices to subsidiaries of western MNEs within the Ghanaian context.

The remainder of this article is organized as follows. In the following section Ipresent the literature review on standardisation of HRM practices, localisation of HRM practices, and integration of localisation and standardisation in a dual approach to HRM practices. The methodology, data analysis, findings and discussions, contributions to theory and practice, suggestions for directions for future research, and implications for practice conclude the paper.

\subsection{Transfer of HRM practices in MNEs}

MNEs aim to transfer to their overseas subsidiaries HRM practices that reflect the core business values and competencies established in the MNEs' home countries. The transferred HRM practices are believed to be sources of synergy, efficiency and competitive advantage (Kostova, 1999). Western MNEs transfer their preferred HRM practices to Africa with the intention to gain perceived advantages of superiority, consistency, effectiveness and competitive advantage (Kamoche \& Newenham-Kahindi, 2012; Mellahi and Frynas, 2003). The transfer of HRM practices is intended to standardize the HRM practices throughout the various units of an MNE, facilitating coordination and interaction (Jain, Lawler, and Morishima, 1998; Festing et al., 2010; Rosenzweig and Nohria, 1994). Such standardization is intended to "smooth the transfer of MNE competencies across the organization" (Wocke, Bendixen, and Rijamampianina, 2007: 829).

Nonetheless, the need for MNEs to adapt their practices to those of the host nations may be attributable to cultural 
differences (Hannon, Huang, and Jaw, 1995), consumer preferences (Prahalad \&Doz, 1999; Bartlett \& Ghoshal, 1989), legal regulations (Kostova\& Roth, 2002) and labor markets (Rosenzweig \& Nohria, 1994). These (and other) factors create pressures for MNEs to decentralize decision-making about HRM issues in order to conform to, and become legitimate in, the local context. The transfer of parent country HRM practices to culturally-distant foreign subsidiaries may be not only ineffective, but also counterproductive (Kim and Gray, 2005). According to Tayeb (2005: 102), whether an MNE acquires a company or sets up a new one in the process of internationalization, the parent company cannot easily eradicate 'its host-country employees' cultural attitudes, values and beliefs (sic) from a distance and through rules and regulations.' For that reason, stakeholders such as local managers and unions are likely to reinterpret, negotiate or adapt selected practices to suit the context (Yahiaoui, 2015).

For effective and appropriate application of foreign HRM practices in Africa, Jackson (2004) suggests that managers should be cognizant of both endogenous and exogenous factors that might influence their decisions and actions. Thus it is reasonable to argue that for Africa a dual management approach incorporating both standardized and localized values, beliefs and practices is vital. Moreover, finding the right balance between standardization and localization can lead to mutual learning and compromises (Gamble, 2003). According to Laurent (1986: 97): 'In order to build, maintain, and develop their corporate identity, multinational organizations need to strive for consistency in their ways of managing people on a worldwide basis....to be effective locally, they also need to adapt those ways to the specific cultural requirements of different societies.'

We suggest that interplay simultaneous application of standardization and localization of HRM practices in subsidiaries of Western MNEs is feasible. The interplay between the two approaches may permit subsidiaries to take advantage of opportunities that stem from the local environment and still fulfil the MNE's expectations of the subsidiary (Mudambi, 2011).

\subsection{Methodology}

I adopt an exploratory case study method for this research because little is known about our research question in the Ghanaian context. An exploratory qualitative case study design is useful for conducting research in a novel context with relatively little research on a 
topic (Zhao, Anand, \& Mitchell, 2005). The focus of exploration is therefore to gain "in-depth understanding of local, emic meanings, and of remaining open to alternative perspectives and tensions in the research setting" (Leppaaho, Plakoyiannaki, \& Dimitratos, 2016: 161) of transfer of HRM practices.

The qualitative approach is useful in explaining the Ghanaian context within which western HRM practices are implemented. It is possible to illuminate meanings and contextual influences on people's perspectives and actions within a certain milieu (Buckley, Chapman, Clegg, Gajewska-De Mattos, 2014; Given, 2008; Maxwell, 2013; Ritchie, Lewis, Nicholls, \& Ormston, 2014; Yauch \& Steudel, 2003) employing qualitative methods. The approach describes situational details and "provides insights that are difficult to produce with quantitative research" through thick and detailed descriptions of events in their natural context (Gephart, 2004: 455). "Up-close qualitative types of methodologies" are appropriate for researching phenomena that require "deep contextual understanding to be meaningful" (Birkinshaw, Brannen \& Tung, 2011: 575). Qualitative approaches can unearth the reality of employees and managers' perspectives and interpreta-tions of HRM practices.
Given the limited research on HRM practices in subsidiaries of western MNEs in Africa coupled with our aim to extendexisting literature, and considering the explorative nature of the research, qualitative approach is appropriate (Regnér \& Edman, 2014). Our research seeks to appreciate and share the experiences of host country managers and employees of transferred HR practices in western subsidiaries.

\section{Selection of informants}

I conducted 37 interviews of both managers and employees in the eight companies from May to July 2015 which lasted on average about one hour per interview. Interview informants include HR director, Area manager, HR managers and employees of participating companies. All interviewees were fluent in English because it is used as the international business language in the subsidiaries. Consequently, I conducted all the interviews in English. I recorded interviews only when participants consented. However, as Hutchings (2004: 143) notes "tape-recording interview notes has been considered de rigueur for modern research" but in my research, not all participants were prepared to have their interviews recorded. Five participants refused to be recorded. In such a situation, I listened attentively and took notes at the same 
time. Then, in order to minimise the richness of data loss, as soon as the interview was over, I quickly typed the notes and emailed them to the interviewee to authenticate. In all cases that I sent these emails, participants made corrections and additions to the texts.

I used documents in this study to triangulate and corroborate interview data. This variety of sources of information offers me the opportunity to look at the phenomenon under investigation holistically with an open mind (Bowen, 2009). If the information contained in the documents is similar to that of the interview scripts, then the confidence and trustworthiness of the qualitative information would have been established. Using documents and interviews as sources of information provides holistic comprehension, digestion and interpretation of the findings about the phenomena under investigation with the possibility of new facts emerging (Jick, 1979; Mok \& Clarke, 2015; Turner et al., 2015; Shah \& Corley, 2006). Thus, in situations of divergence in findings from these multiple sources of data, further probing and seeking new alternative explanations could be generated to explain the phenomena (Denzin, 2012; Gibbert \& Ruigrok, 2010; Guion, Diehl, \& McDonald, 2011; Hoskisson et al., 2000; Jick, 1979).

\section{Data analysis and findings}

Iemployed both deductive and inductive approaches in analysing the data. The deductive approach uses an organising framework comprising of themes for the coding process (Bradley, Curry \& Devers, 2007; Bruan \& Clarke, 2006; Miles \& Huberman, 1994). The framework, often referred to as a start list (Miles \& Huberman, 1994), is applied in the analysis in anticipation that certain core concepts are in the data (Bradley et al. 2007; Thomas, 2006).

The start lists provided initial focus in identifying certain key aspects of the data that directly relate to the research questions. I entered the interview transcripts as text files to NVivo software version 11 to code the data based on Nvivo codes using partici-pants' own expressions, terms and phrases (see Corley \& Gioia, 2004; Dacin et al. 2010; Gioia, Corley, \& Hamilton, 2013; Petriglieri, 2015). I deductively analysed the raw data to develop clusters of data. The application of HQ rules and regulations, manuals by HQ personnel to subsidiaries signify standardisation of HRM practices while issues portraying power distance, selective patronage, and centralised decisionmaking, influence of chiefs or politicians and favouritism reflect localisation. 
Having developed clusters of data from the deductive analysis, I also conducted an inductive analysis and assigned codes to paragraphs or segments of texts relevant to the research questions. I identified key concepts and themes using the research questions as the lenses. Deriving themes from the raw data using the inductive approach preempts the possibility of a researcher forcing a predetermined result (Bradley, Curry, \& Devers, 2007; Braun \& Clarke, 2006; Glaser, 1992).

The sequential approach using deductive and inductive analysis resulted in two data sets of categories which Ireduced to manageable sizes by collapsing similar categories into higher order ones. I cross-tabulated data to examine relationships among categories (see Suter, 2012).

\subsection{Findings}

This section presents the findings of the empirical investigation. I analysed western MNEs' standardisation and localisation of recruitment and selection, training and development practices.

\section{Standardisation of HRM practices in subsidiaries}

Recruitment and selection

Subsidiary recruitment and selection practices largely focus on hiring persons with best fit for roles through the implementation of succession plans and funnel approaches. Seven of the eight subsidiaries have succession plans in place. These subsidiaries are the American extractive company USA1, the British manufacturing and distribution of household consumables company UK1, the British beverage manufacturing company UK2, the British Bank UK3, the French Bank F1, and the German courier G1. The American courier, the Licensee, has no succession plans in place and the HR Manager claimed that the company was still young after being in operation for almost twenty-two years.

\section{Succession Planning}

Succession planning seeks to fill vacant positions with internal candidates. These are existing employees who have distinguished themselves through high performance. These high performing employees are classified as "high flyers" (IsaUK2); "people with stretch potential" (AbaUK2-Mketing Mger); and "covers for various positions" (AlbertoF1-HRMger). These persons are given "challenging jobs" (Rober- 
tiS1-HR Mger) and put on the "radar of the company" (FramG1-HR Mger). According to the HR Director of UK2

Succession planning is done through audit of the people balance sheet. This involves an audit of the existing talent pool. We start from head count, age analysis, tenure in position analysis, exit analysis and finally you populate your people in a quadrant where you have people with very high potential, medium potential, low potential and vexation potential. Vexation means you have the potential to grow and perform better but you are not doing it. Psychologists call it fixated" (TurayUK2-HR Director).

Preference is given to existing employees to assume higher roles because they have acquired the tacit knowledge and understood the norms and values of the business.

Furthermore, outstanding employees are put on a career plan. The employee is intermittently evaluated to determine whether he/she is fulfilling certain roles, taking on additional responsibilities or acting successfully in certain roles when his/her superior is not there. The HR Manager for the French bank F1 corroborates with the above arguments stating that
Some local companies do not care who comes to fill their role. They do not keep a talent pool, without knowing that if you keep a talent pool, and there is a vacancy, you do not need too much time to push the person there or to help that person to be able to fit that role, forgetting that if the person is not able to fit the role earlier, productivity will suffer and it will have direct impact on the cash flow. This is because the time you are supposed to use to get the job done, you are training the person or somebody is virtually leaving his/her job to help that person do his work (BertoF1-HR Mger).

Subsidiary USA2, the American courier licensee, has no succession plans in place. A possible explanation is that all the directors are Ghanaians. Vacant positions are therefore likely to be filled not based on competence but on 'whom you know.' Any suggestion to management about having succession plans in place is likely to be interpreted to mean wanting the downfall of a superior; which can trigger animosity in the work environment. The lack of succession planning in such circumstances can lead to inability to take certain strategic decisions in the event of strategic positions such as chief executive position becoming vacant. 
Funnel approach

The eight subsidiaries use funnel approaches to filter from the large pool of job applicants in order to arrive at best-fit for roles. The funnel approach which refers to the steps in recruitment and selection practices entails inviting a large pool of job applicants and selecting the best. With the exception of the American licensee company, USA2 that mostly relies on unsolicited applications, all other seven subsidiaries often advertise vacant positions through their company portals. Job applicants in all subsidiaries are usually required to sit an aptitude test. Selecting job applicants through a test is regarded as fair and transparent. According to an employee of the Swiss oil company S1, "there is nothing like whom you know here. You need to be qualified for you to be hired. Even if it is your sister, husband, or friend in-charge, you still cannot be employed if you do not pass the aptitude test. That is the culture" (RoyS1-Emp). Similar views are expressed in the other subsidiaries. MNEs use tests as a way of controlling and limiting the discretion of subsidiary managers in decisions relating to recruitment and selection practices. These tests are also used to ensure that successful applicants are the most suitable by corporate HQ standards.
Additionally, job candidates who pass the test have to attend interviews. At executive level, job candidates are sometimes interviewed at the global corporate HQs. For instance, in the American extractive company USA1, executive level job candidates are sent to Denver where they undergo several screening interviews. This extractive company also executes a distinctive recruitment and selection process called opportunistic hiring. The HR Manager explains that

We do what we call opportunistic hiring, which is before the position becomes vacant, if we know we don't have an internal candidate, we start to profile people. Let's say, Mine Manager, we know we don't have an internal candidate, we profile all the mine managers in Ghana to know who the best is. We actually go and talk to the person and ask if he/she is interested in a particular role" (BiyarUSA1-HR Mger).

Interviews, both at the subsidiary and corporate level, are meant to ensure that candidates possess the job attributes considered success factors by MNE control standards. These are control mechanisms put in place to determine membership of the corporate family. Tests and interviews are also considered standardised procedures in formalising HRM practices at subsidiaries. Although tests and interviews are also used in 
indigenous organisations for recruitment and selection, an interviewee revealed that "some persons are recruited into certain roles not based on their performance at the test or interview" (AlorUK3-Emp).

The scarcity of talent in the host context leads subsidiaries to poach from their competitors by offering wage premiums. The HR Manager for G1 reveals how he was employed "it is a poaching sort of situation - where I was contacted by an agency" (FramG1-HR Mger). Similarly, at USA1, the HR Manager explains that "we also do head hunting" (BiyarUSA1-HR Mger).

\section{Training and development}

The components of training and development programmes in the subsidiaries, comprising HQ manuals and instructions and training infrastructure. Subsidiary training and development programmes are designed to assist employees to acquire the necessary com-petencies and skills in order to bridge performance gaps. Training and development also help employees cultivate the necessary corporate identity. The HR Manager of the British manufacturer of alcoholic and non-alcoholic manufac-turer UK2 defines training as the process of upskilling employees "so that if there is any vacancy, filling that role will not be a problem because the people are skilled anyway and also to address specific problems in specific departments for specific individual employees" (IsaUK2HR Mger). In building these competencies and skills, subsidiaries use corporate HQ training manuals and instructions with appropriate training infrastructure.

\section{HQ manuals and instructions}

Training manuals, competency guides, training at the regional and corporate HQs, seminars, conferences and virtual networks of HR managers facilitate the standardisation of parent company training practices at the subsidiary level. Training content is derived from manuals designed at corporate HQ. For the French bank F1, the HQ designs training programmes "related to managerial efficiency and leadership skills" (AlbertoF1-HR Mger); the British firm UK1 uses the "Manchester policy as a guide" (MarvinUK1-HR Mger) while USA2 uses a "standard manual for training that comes from HQ" (Mulka USA2-HR Mger). The HR Manager for UK2, surmised that "there is the HR manual which has been developed at the headquarters to which we refer to, to ensure that we are aligned. So for all practices with regards to $\mathrm{HR}$, we refer to the HR manual" (IsaUK2-HR Mger). MNEs seek to formalise the procedures 
for the implementation of HRM practices by applying these manuals. Subsidiary managers are constrained in their decision-making process due to the application of com-mon procedures and processes in their training and development programmes.

Furthermore, to facilitate the identification of employee training needs, UK2 uses competency guides. An employee of UK2 revealed that

We do what we call competencies acquisition process (CAP). This CAP is developed at the HQ. These are assessments that are conducted for all job holders in this company. All jobs in this company have a competency guide. Competencies guide refers to the skills that are required for every job holder in his/her area to function very well on the job (AbiUK2-Emp).

Other subsidiaries call it (CAP) the personal development plan (PDP) which helps the employee to know his/her training needs. The competency guides serve as signposts for desired work attributes and behavioural practices aligned with MNE corporate culture.

In addition to training manuals, competency guides and personal development plans, subsidiary officials are trained at HQ. For instance in the French bank F1, there are "attachment opportunities for specific roles at the HQ in Paris" (NiliF1-Emp), while for USA1, the HR manager explains "for my role, at least I go to the head office once a year, when we are doing our strategy because some of the work that I do is driven by the corporate side"(BiyarUSA1-HR Mger). Visits to HQ by subsidiary managers serve as opportunities to share information on corporate vision, mission and culture face-to-face with HQ managers. Subsidiary managers get to know more of the goals, culture and decision-makers of HQ, which also has the potential to enhance their tacit knowledge. They may begin to see themselves as members of the corporate team.

Subsidiaries equally receive training from their regional hubs. In the American courier licensee, USA2, Dubai provides "training for the sales team" (RoeUSA2-Emp) while for G1, trainers from South Africa "come in to train us on new practices within the group" (EtoG1-Emp). Also, there is a virtual network of HR managers of subsidiaries USA1, UK1, UK3, F1, G1 and F1. HR Managers organise monthly video and phone conferences to discuss corporate global policies. All these interactions between subsidiaries and regional HQs as well as corporate HQ lead to building and solidifying employees into a corporate family. Subsidiary managers 
come to appreciate their roles and those at HQs better and are likely to develop a shared understanding of corporate values.

\section{Training infrastructure}

With the exception of the American courier licensee USA2, the other seven subsidiaries have training infrastructure in place including company portals, schools and centres. The British Bank UK3, and the German courier company G1 and the Swiss downstream oil company S1 have online portals with pre-designed training programmes from corporate HQ. An employee at G1 states, "We have a training platform even if you are in Bonn or in Ghana, it is the same training platform for everybody, the same courses accessible to us and the sort of training that is received there, is the same training that we also get here" (EtoG1-Emp). Expressing similar views about the online training portal, an employee of UK3 notes that

It is computerised, it is electronic. It is not like you have to lobby your way like the Ghanaian system, no, you key everything in and then it populates. For instance, at the end of year, even as part of the talent management system (TMS), what I do as training is different from what my colleagues will do. The TMS has so many courses, so many topics and so many areas. You go into it and you pick any of them (WesehUK3Emp).
These online training programmes provide consistency in the level of skills required by subsidiary employees in order to be integrated into the HRM practices of corporate HQ. These online training programmes are mandatory for all employees and to underscore the seriousness attached to these training programmes, a participant explains

Excuse me to say they are more serious. Even if you skip any training, you will not be comfortable on the job because you are expected to produce a certain level of returns or a certain level of output so if you are not better equipped, there is no way you can bring that up" (MayaUK3-Emp).

Subsidiaries have little option other than to comply with and implement these training programmes. These training programmes are integrated electronically which is regarded as cost efficient compared to sending expatriates to subsidiaries to provide training. These electronic platforms serve to integrate all subsidiaries within the MNEs.

The British and the French banks (UK3 and F1) have each established training schools/centres for junior and middle level managers. These training centres are strategically located in Accra and Kumasi to serve the southern and northern sectors of the country respectively. The American mining company 
USA1, on the other hand, has instituted a four year certified apprenticeship training programme for technical training. These trainings are instructorled and simulations are also used for different types of workflow processes. These training schools/ centres serve as grounds for sharing the values of MNEs.

\section{Localisation of HRM practices}

The host country cultural and institutional forces such as the influence of traditional leaders as land owners, presence of unions in subsidiaries, community agitations in catchment areas of the subsidiaries, politicians and the appointment of host country nationals in key positions relating to the implementation of HRM practices result in localisation of some HRM practices. Figure 5.6 shows data on localisation of HRM practices.

Recruitment and selection: The role of informal institutions

The recruitment and selection practices in relation to localisationEvidence from the interviews suggests that informal institutions play a crucial role in the implementation of the hiring process, particularly in the extractive industry of the American company USA1. USA1 has developed what the company termed as "our local, local policy"for recruitment and selection at the mining sites.
Local, local because the Regional HQ is in Ghana and there are mining sites as well. The mining sites are referred to as local, local.

The HR Manager explains that through the local, local policy, "We have a certain quota that we have agreed with the communities that at every point in time, a certain percentage of our workforce will be from the communities that we are working within. Different communities, different sizes have diffe-rent quotas and different agree-ments" (Biyar USA1-HR Mger). The chiefs and their communities have given their land which serves partly as their source of livelihood to the mining company for the extraction of minerals. In exchange for the valuable resources extracted from the land of which the chiefs are stewards, USA1 has to employ members of the mining communities who might have lost their source of livelihood from farming on those lands. Consequently, USA1 has built a community post that liaises with the mining communities.

We cannot be tracking that quota from a regional perspective. We would have to do that from a site perspective so the site HR group make sure they are tracking that. They make sure that when they are recruiting, they are checking to see that the person is from the community. We have our staff working in the post in the community. There are forms in this 
office where by an individual recruited within the quota system of a particular community will have to complete a form which has to be validated by the chief or opinion leader that the person is from the community (BiyarUSA1-HR Mger).

Also, USA1 has put up notice boards within the mining catchment areas where job vacancies are usually posted. "There are company notice boards in all communities within the mining catchment area and adverts are usually placed on these notice boards" (GeoUSA1-Emp). The mining communities are rural areas in Ghana with high illiteracy, lack of newspapers and internet facilities. Thus, mounting of notice boards is probably a pragmatic way in reaching out to the communities and announcing job vacancies. It also brings transparency into the recruitment process such that no particular community can accuse management of not publicising job openings or giving favours to some communities to the neglect of others.

USA1 has also instituted a three year certified apprenticeship training programme and it enrols young persons in the mining communities to build their skills at the company's expense. These trained personnel then serve as a reserve talent pool that the company can employ from, as and when the need arises. "When there is a vacancy, they just call you, they no more advertise" (GonaUSA1Emp). The youth in the mining communities lack the requisite skills and probably only a few of them have acquired primary or secondary edu-cation. Providing them with apprenti-ceship training is perhaps the best appr-oach for meeting the employment quota systems signed with the chiefs. Therefore, for the youth in these mining rural communities, there is the need to provide them with apprenticeship training. Documentary sources revealed that in 2012, 26 electrical and mechanical apprentices graduated from the training programme. With the acquisition of the skills, they can equally seek jobs in other companies since they are not bonded to serve USA1. The apprenticeship programme promotes community goodwill for USA1.

Particularism is practiced in the subsidiaries, such that some employees are hired based on technical "know who" instead of technical "know-how". Instances that illustrate particularism include

"Favouritism still exists "(JoF1-Mger); "people come in and tell you they don't know anybody here but when they get on board, you realise that they know people. So definitely somebody might have influenced their employment" (BelG1-Emp); "you know it is a human institution, you can't be so sure" (MayaUK3-Emp). 
A shareholder of UK3 wrote "many highly qualified staff have been denied roles in favour of unqualified cronies of top Managers and Directors" (Ghanaweb sources). Another employee states "every organisation has that aspect" (WesehUK3-Emp). Cronyism also exists with the popular saying "you scratch my back and I will scratch yours." Persons in responsible positions may help relatives of their colleagues secure jobs in their work places and also expect the same to apply to them. An employee at USA1 explained that some job candidates secure employment "through the big men in the company, those who have links with them and some too through government ministers" (GonaUSA1). Government ministers are influential in matters relating to acquisition and renewal of licenses by MNEs to operate and comply with environmental laws such as pollution. It is likely that a government minister who is in a position to influence any of these outcomes for a subsidiary can equally secure job opportunities in subsidiaries for cronies and relatives.

\section{Training and development}

The major themes on localisation of training and development, namely power distance and cronyism and prejudice in selecting trainees.

\section{Power distance and cronyism}

Employee training and development are accessed not only based on needs assessments but also on favouritism. The power distance that characterises the cultural and institutional context provides management with a paternalistic role to determine the training needs of employees. In the French bank F1, for instance, management draws up training programmes and nominates employees to attend, based on their work schedules. As a result, not all employees have the opportunity to be trained during the course of a year. An employee of S1 explains that training depends on your rank and your responsibilities. "If management believes that your role does not require any training, you are not trained" (RalfS1-Emp). Management has the prerogative to determine who should be trained rather than according to the needs of the job. Similarly, a participant at the American mining company states that It is my head of department who identifies my training needs. You don't choose the type of training you need because they (heads of departments) know the training that is suitable and nominate you to go for the training. It is the manager who identifies the training because he knows the type of training that will help his/her department" (GonaUSA1-Emp). 
The HR Manager for the British firm UK2, emphasises that "the functional head and the manager know the employee too well and they know which areas the employee needs training in" (IsaUK2-HR Mger). The employee basically depends on the paternal instructions of the manager who decides on the type of training to be conducted for the employee.

As a result of the power distance, managers often prefer to give training opportunities to their favourite employees. A participant explains that

If you are not in the good books of your manager, you will not be chosen for training. For the expatriates they are fair in their choices and employees are selected for training depending upon their competencies and potential. For the Ghanaians, only few are sincere and will select persons for training based on their competencies" (GeoUSA1-Emp). Thus cronyism seems to characterise the process of selecting employees for training.

\section{Prejudice in selecting trainees}

In addition to favouritism, some subsidiaries focus their training and development efforts only on employees directly linked with revenue generation. For instance, in the American courier licen- see USA2, the HR Manager described how she was refused training, for the reason that she has already learnt all that in school. She points out, "Not everybody gets the opportunity to be trained because normally our focus is on front desk/customer service. HR and accounting personnel are not given opportunity to be trained because management believes that they are not core to the business" (MulkaUSA2-HR Mger). In the British beverage manufacturer UK2, similar views are expressed that "most of these trainings are usually done for the sales department because they bring the money. So they (Management) are always interested in them" (FloraUK2Emp).

Employees who contribute more to the competitive advantage of the subsidiary are usually provided with more opportunities to be trained. This probably confirms the assertions of an interviewee that "Ghanaian indigenous companies want to use you but not to impart knowledge. When you do that the company suffers because the companies are not ready to invest in their employees. In the local companies, you get people with big titles but they are not doing anything" (IsaUK2-HR Mger). Prejudice in selecting trainees can break down team spirit and cooperation with a resultant sub-optimisation of the subsidiary's performance. 


\subsection{Discussion and concl- usion}

\section{Ethnocentric and polycentric HRM practices}

The findings reveal key institutions that influence the transfer of ethnocentric HRM practices and the countervailing polycentric practices in the host context, resulting in an interplay of localisation and standardisation. I examine the research questions in the following sections beginning with the influence of the normative institutional distance on standardisation and localisation of HRM practices in Ghana.

\section{Ethnocentric HRM practices}

The findings demonstrate that subsidiaries use recruitment and selection practices that are relevant to task performance by filling vacancies with high performing employees using objective and transparent criteria. Selection is based on merit. Subsidiaries identify talent based on the value and potential of employees as high performers to fill vacancies. High per-forming employees are assumed to be familiar with and knowledgeable of corporate HQs' cultures. Iles, Chuai and Preece (2010) observed that organi-sations usually invested in their high perfor- ming employees as a strategy to curtail hiring and training costs associa-ted with employing new employees - and this approach was adopted by MNEs in this current study.

The findings further show that subsidiaries engage in poaching and headhunting for job candidates offering wage premiums in line with corporate HQ strategies to gain superior skills and knowledge. The Ghanaian job market lacks experienced, professional technical and managerial staff, largely due to the mismatch between the needs of industry and skills thatgraduates acquire from tertiary institutions (Osabutey \& Debrah, 2012; Osabutey, 2013). The shortage of requisite skills in the host context to meet the efficiency expectations of MNEs leads to competitive hiring strategies. Ghanaian indigenous firms have resource limitations, particularly in relation to finance, and may not be able to engage in poaching and headhunting. Generally, western MNEs usually pay higher wages with better working conditions than Ghanaian local firms (Akorsu, 2011). Subsidiaries engage in poaching and headhunting as key sources of gaining competitive advantage over their competitors in terms of skilful, knowledgeable and talented employees 
The findings further suggest that subsidiaries are investing heavily in training and development programmes based on needs such as induction training to socialise new employees into corporate HQ culture, learning of new developments and addressing performance gaps. Training and development of subsidiary employees are crucial since technical and managerial staff are lacking in the host context. Training needs are determined from employee performance outcomes. Furthermore, some of the content of training and development practices of subsidiaries emanate from corporate HQs with limited or no input from the local context (see Mamman et al. 2009) specifying the type of competencies required for certain tasks. The findings revealed that subsidiaries provided internal training in training centres / schools to educate their employees on new developments concerning their work.

Training and development practices in subsidiaries are meant to improve employees' personal and organisational skills and capabilities in order to compete satisfactorily (Rosenzweig \& Nohria, 1994). MNEs institutionalise their training programmes in subsidiaries because host context employees often lacked the requisite knowledge and technological skills for competitive business. Additionally, the current study highlights the use of in-patriates who are instrumental in giving advice on how to appropriately standardise HRM practices. In-patriates usually received corporate HQ level training and are in a better position to interpret corporate goals, policies and their implications for the local context (Harvey et al., 2000; Kynighou, 2014). Giving opportunities to subsidiary employees and managers to work in corporate HQ and other subsidiaries exposes them to MNE corporate wide goals and structures as well as its diversified nature. Employees learn more about how their individual roles and that of their subsidiary fit into the corporate structure (O'Donnell, 2000). Employees might recognise and accept other cultural values other than their own and as a result minimise any stereotyping within the MNE. Kynighou (2014) pointed out that in-patriates are often used strategically by corporate HQ for the transfer of HRM practices.

\section{Polycentric HRM practices}

The findings reveal that contrary to the expectations of corporate HQ where non-performing employees are usually redeployed with such roles typically outsourced, this category of employees have kept their jobs in alignment with the paternalistic culture with the Ghanaian maxim "yetease nti na metease I live because we live" (Opong \& Gold, 
2016: 352). Supervisors and managers tend to behave with paternal responsibility towards employees (AmoakoAgyei, 2009). Gyekye and Salminen (2005: 45) explained that the paterna listic managerial style in Ghana's work environment developed its strength from the traditional belief that top management is responsible for the welfare of employees. Managers are involved in the social life of employees such as weddings, outdooring ceremonies and bereavement.

Another possible reason for keeping non-performing employees in their positions may be linked to AmoakoAgyei's (2009: 335) observation that the African manager will not usually dismiss an employee outright for non-performance, because "socially and financially, the communal consequences may be far greater and longer-lasting than the act itself", particularly where an employee was hired because of the influence of a respected member of a society. Outright dismissal might incur retaliatory responses, particularly if the subsidiary is dependent on resources held by relations of the dismissed employee.

Moreover, in Africa, recruitment and selection decisions are usually associated with nepotism and are not taskcentred. In a study of French subsidia- ries in Tunisia, Yahiaoui (2015) observed that subsidiary managers complemented recruitment and selection with wasta based on interpersonal relations / nepotism. In Ghana, Debrah (2001) and Akuoko (2008) observed that recruitment and selection are likely to be based on tribalism and personal contacts play significant roles in securing jobs for members of an in-group. Job applicants belonging to the same in-group with subsidiary managers are likely to have comparative advantage in the selection process. Employment of relatives is seen as an 'obligation' in fulfilling one's duties to members of the in-group. A person may risk being ostracised and vilified for not fulfilling this role. For example people may say "he/she only helps outsiders to the neglect of his/her own people."

The findings further indicated that training and development practices were based on selective patronage. Aycan (2005) observed that decisions on who will participate in training in nonwestern contexts depends on employees cultivating good relationships with management, particularly for very attractive training such as overseas training programmes. Kuada (1994) points out Ghanaian managers provide extra opportunities for subordinates for whom they have affection. Subordinates in turn preoccupy themselves to become 
likeable rather than relying on their own competence. Managers are assumed to be experts and are expected to provide direction and instructions. Employees do not resist management authority and are required to show respect and deference in return for support (Aycan et al., 2000; Jackson, 2016). It is considered rude for employees to argue with their superiors. Subsidiary managers provide advice to employees on personal and work matters which may be considered interfering from a western perspective (Amoako-Agyei, 2009). Many organisations in Ghana are unable to invest in their employees due to lack of resources as a result few opportunities exist for employees to undergo training. Additionally, career planning is largely ignored in Ghanaian organisations (Debrah, 2001; Haybatollahi \& Ayim, 2015).

\section{Interplay of standardisation and localisation of HRM practices}

In this section, I examine the second main research question which states: How do western MNEs manage the interplay between localisation and standardisation of HRM practices in Ghana? The findings reveal that Western MNEs seek to rely on corporate HRM practices that "reflect an ethnocentric ethos" (Siebers et al., 2015) because of the conviction that if they followed local practice the subsidiary would not be financially competitive with other organisations (Bjorkman \& Budhwar, 2007) and would not align with the business strategy of the MNE's operations. Furthermore, Lu and Bjorkman (1997: 621) postulated that "in general MNE standardisation and localisation were opposite to each other or incompatible with each other", but my research findings provide evidence that standardisation and localisation of HRM practices are implementable concurrently. Thus, whilst Western MNEs engaged in forward diffusion of their preferred HRM practices because of the perceived advantages, HCNs, unions, chiefs and employees of the host context also have considerable interests and influence on how corporate policies translate into practices at the subsidiaries. Thus, the transfer to, and implementation of, HRM practices in subsidiaries becomes a contested and shifting process (Gamble \& Hung, 2009), with host country institutional provisions partly shaping HRM practices.

The findings agree with previous research that HRM practices have varied degrees of standardisation and localisation (Rosenzweig \& Nohria, 1994). As discussed in this chapter, because of the technological distance between Ghana and parent countries of MNEs, coupled with the latter's econ-omic 
sophistication, the MNEs succee-ded in imposing their ethnocentric practices such as succession planning, company portals for training and deve-lopment, contingent rewards, employee participation and to a limited degree flexible work programmes. However, efforts to determine and control the implementation of HRM practices in subsidiaries are constrained by workers, HCNs, unions and traditional leaders who seek to protect their interests.

This study demonstrates that the cultural and institutional characteristics of the host context play significant roles in shaping the behaviours and management styles of HCNs. Thus, certain practices are localised due to the presence of HCN managers. For instance, subsidiary managers are likely to select their favourites to occupy strategic positions as part of the succession planning process. This assertion is supported by Kuada (1994) who stated that Ghanaian managers are usually selective in their patronage to subordinates by giving privileges and opportunities to employees deferential to them. This can affect all the other HRM practices, for instance training and development, employee communication and participation. This finding is consistent with the extant literature that HCNs are likely to be committed to the host country and as such are responsive to the local cultural and institutional demands which provide subsidiaries with legi-timacy (Michailova, Mustaffa, \& BarnerRasmussen, 2016). This asser-tion also supports Mamman et al. (2009: 4) who conclude that "even if MNEs adopt an ethnocentric policy, local managers would modify the system anyway." The findings further confirm the assertion by Tayeb, (2005: 102) that whether a subsidiary is an acquisition or green-field, an MNE cannot easily eradicate "its hostcountry employees' cultural attitudes, values and beliefs from a distance and through rules and regulations."

The findings further show that local employees and unions have expected practices such as welfare services for employees and their families, including healthcare and bereavement leave which are characteristic of the collectivist and paternalistic Ghanaian context. This finding concurs with Scott (1983: 16) that "constituents all participate in and are carriers of the culture" while Kim and Gray (2005: 823) observe that "HRM deals with people who are the main carriers of the cultural values." It is the institutional context that gives meaning to HRM practices of subsidiaries through employees who are regarded as "carriers of institutions" (Kostova \& Roth, 2002: 218). Thus employees seek to understand subsidiary HRM practices using an interpretive 
frame embedded in the local cultural and institutional context.

\subsection{Contributions to theory and practice}

Herein I discuss the contribution of this study to the scholarly conversation in IB and how it partly addresses the paucity of literature available on the transfer of HRM practices in subsidiaries of western MNEs in Ghana. I highlight through empirical case studies the range of distinct heterogeneous cultural and institutional features of Ghana that affect MNEs' strategic choices and practices.

Contrary to the neo-institutionalists who view organisations as complying fully with host country's institutions, this study demonstrates that subsidiaries are not "passive pawns" (Tempel \& Walgenbach, 2007: 10) but are actively engaged in the interpretation of norms according to their self-interest (Mudambi, \& Navarra, 2002). Thus, by combining neo-institutionalism and the old institutionalism, this study reveals how MNEs are in some cases able to act according to their preferences, despite being constrained by institutional forces. Thus host country institutions are also partially shaped in line with the preferences of MNEs (Jackson \& Deeg,
2008). The existing cultural and institutional forces of the host country interact with HRM practices that have been developed, nurtured and embedded in the norms and values of the home countries of western MNEs, thus influencing the meanings, interpretations and implementation (Anakwe, 2002) of HRM practices.

The research constitutes a current and relevant source of empirical information about HRM practices of foreign subsidiaries in Ghana. The findings could be applicable to other African settings exhibiting similar features to the host context. The findings support what Kvale (1996: 233) describes as analytical generalization that "involves a reasoned judgement about the extent to which the findings from one study can be used as a guide to what might occur in another". My study therefore extends the scope of the existing literature in IB by incorporating knowledge of the transfer of HRM practices from this part of the world.

The practical implications of this research point to the need for HQ executives in the parent country to carefully evaluate the institutional environment of the Ghanaian context before making decisions on the suitability of transfer of particular HRM practices. Prior experience gained in African contexts, inclu- 
ding other developing countries, may not necessarily be transferrable to, and useful in, the Ghanaian context. Ghanaian HCNs may act as an invaluable conduit between the subsidi-aries and senior HQ executives in explaining and making sense of the specificities of the host context which MNEs need to consider if they are to be successful in achieving their strategic business and HRM goals. HCNs can share their experiences with expatriates and HQ in conferences, meetings and training sessions at subsidiaries and during visits by HQ officials.

\subsection{Limitations and dire- ctions for future research}

The research has some limitations that suggest grounds for future research. The methodological limitations pertaining to the study were discussed in chapter four of this thesis and include replicability, subjectivity, and generalisability. For instance, qualitative data collection, analysis and interpretations are subjective and liable to researcher's biases (Bryman \& Bell, 2015; Denzin \& Lincoln, 2011). The researcher brings his/her values into the research process.
Thus, in order to minimise bias, I triangulated interviews with documents in order to crosscheck and validate the evidence (as illustrated in chapter five).

It is acknowledged that a limitation of this study is that the sample size is relatively small and differed substantially between subsidiaries with the lowest being three and the highest seven participants respectively. Even though the difficulties of gaining access were explained in chapter four and the study involved very in-depth analysis, future research should endeavour to examine alternate approaches to achieve a larger sample.

Also a potential limitation of this research is the inherent retrospective bias of interviewees concerning past events (see York, Hargrave, \& Pacheco, 2016). I sought to minimise these biases which may occur in cross-sectional data collection by triangulating interview data with documents, but future research might address this issue by examining individuals' perceptions across several points in time. 


\section{References}

Adams, K., Nyuur, R. B., Ellis, F. Y., \& Debrah, Y. A. (2016). South African MNCs' HRM systems and practices at the subsidiary Level: Insights from subsidiaries in Ghana. Journal of International Management. http://dx.doi.org/ 10.1016/j. intman.2016.07.001.

Amoako-Agyei, E. (2009). Cross-cultural management and organisational behaviour in Africa. Thunderbird International Business Review, 51(4), 329-339.

Aryee, S., (2004) 'HRM in Ghana'. In Kamoche, K., Debrah, Y.A., Horwitz, F.M. and Muuka, G.N. (eds). Managing Human Resources in Africa. London: Routledge, pp. 121-34.

Aycan, Z. (2005). The interplay between cultural and institutional/structural contingencies in human resource management practices. The International Journal of Human Resource Management, 16(7), 1083-1119.

Aycan, Z., Kanungo, R., Mendonca, M., Yu, K., Deller, J., Stahl, G., \& Kurshid, A. (2000). Impact of culture on human resource management practices: A 10-country comparison. Applied Psychology, 49(1), 192-221.

Aycan, Z., Schyns, B., Sun, J. M., Felfe, J., \& Saher, N. (2013). Convergence and divergence of paternalistic leadership: A cross-cultural investigation of prototypes. Journal of International Business Studies, 44(9), 962-969.

Bradley, E. H., Curry, L. A., \& Devers, K. J. (2007). Qualitative data analysis for health services research: developing taxonomy, themes, and theory. Health Services Research, 42(4), 1758-1772.

Braun, V., \& Clarke, V. (2006). Using thematic analysis in psychology. Qualitative Research in Psychology, 3(2), 77-101.

Bryman, A., \& Bell, E. (2015). Business Research Methods. UK: Oxford university press.

Buckley, P. J., Chapman, M., Clegg, J., \& Gajewska-De Mattos, H. (2014). A linguistic and philosophical analysis of emic and etic and their use in international business research. Management International Review, 54(3), 307324.

Budhwar, P.S., \& Debrah, Y.A. (eds). (2001). Human Resource Management in Developing Countries

Cooke, F. L., Wood, G., Horwitz, F. (2015). Multinational firms from emerging economies in Africa: implications for research and practice in human resource management, The International Journal of Human Resource Management, 26(21), 2653-2675 
Corley, K. G., \& Gioia, D. A. (2011). Building theory about theory building: what constitutes a theoretical contribution? Academy of Management Review, 36(1), 12-32.

Dacin, M. T., Munir, K., \& Tracey, P. (2010). Formal dining at Cambridge colleges: Linking ritual performance and institutional maintenance. Academy of Management Journal, 53(6), 1393-1418.

Davis, D. N., \& Luiz, J. M. (2015). The devolution of the human resources function in South African multinational companies. The International Journal of Human Resource Management, 26(21), 2763-2785.

Denzin, N. K., \& Lincoln, Y. S. (2011). The Sage Handbook of Qualitative Research. Thousand Oaks, CA: Sage Publications.

Ghana Investment Promotion Centre. (GIPC). (2015). Second Quarter Report, (10)4. Accra, Ghana. Available at:www.gipcghana.com/press.../11-2013.html?... 2013-investment-report accessed. 18 February, 2016.

Ghana Investment Promotion Centre. (GIPC). (2016). Third Quarter Report, (12)3. Accra, Ghana. Available at:www.gipcghana.com/press.../112013.html?...2013-investment-report accessed. 18 February, 2016.

Gibbert, M., Ruigrok, W., \& Wicki, B. (2008). What passes as a rigorous case study? Strategic Management Journal, 29(13), 1465-1474.

Gioia, D. A., Corley, K. G., \& Hamilton, A. L. (2013). Seeking qualitative rigor in inductive research notes on the Gioia methodology. Organisational Research Methods, 16(1), 15-31.

Harvey, M. G., Novicevic, M. M., \& Speier, C. (2000). An innovative global management staffing system: A competency-based perspective. Human Resource Management, 39(4), 381-394.

Haybatollahi, M., \& Ayim, S. G. (2015). Organisational citizenship behaviour: A cross-cultural comparative study on Ghanaian and Finnish industrial workers. Scandinavian Journal of Organizational Psychology, 7(1).

Horwitz, F. M. (2012). Evolving human resource management in Southern African multinational firms: Towards an Afro-Asian nexus. The International Journal of Human Resource Management, 23(14), 2938-2958.

Jackson, G., \& Deeg, R. (2008). Comparing capitalisms: Understanding institutional diversity and its implications for international business. Journal of International Business Studies, 39(4), 540-561.

Jackson, T. (2014). Employment in Chinese MNEs: Appraising the Dragon's Gift to Sub-Saharan Africa. Human Resource Management, 53(6), 897-919.

Jackson, T. (2016). Paternalistic leadership: The missing link in cross-cultural leadership studies? International Journal of Cross Cultural Management, 16(1), 3-7. 
Kamoche, K., \& Siebers, L. Q. (2015). Chinese management practices in Kenya: toward a post-colonial critique. The International Journal of Human Resource Management, 26(21), 2718-2743.

Kamoche, K., Siebers, L. Q., Mamman, A., \& Newenham-Kahindi, A. (2015). The dynamics of managing people in the diverse cultural and institutional context of Africa. Personnel Review, 44(3), 330-345.

Kim, Y., \& Gray, S. J. (2005). Strategic factors influencing international human resource management practices: an empirical study of Australian multinational corporations. The International Journal of Human Resource Management, 16(5), 809-830.

Konopaske, R., \& Ivancevich, J. M. (2004). Global Management and Organizational Behaviour: Text, Readings, Cases and Exercises. New York: McGraw Hill Companies.

Kostova, T. (1999). Transnational transfer of strategic organisational practices: A contextual perspective. Academy of Management Review, 24(2), 308-324.

Kostova, T., \& Zaheer, S. (1999). Organisational legitimacy under conditions of complexity: The case of the multinational enterprise. Academy of Management Review, 24(1), 64-81.

Kostova, T., Roth, K., \& Dacin, M. T. (2008). Institutional theory in the study of multinational corporations: A critique and new directions. Academy of Management Review, 33(4), 994-1006.

Kostova, T., Roth, K., \& Dacin, M. T. (2008). Institutional theory in the study of multinational corporations: A critique and new directions. Academy of Management Review, 33(4), 994-1006.

Kuada, J. (1994), Managerial Behaviour in Ghana and Kenya - A Cultural Perspective, Aalborg University Press, Aalborg.

Kvale, S. (1996). Interviews: An Introduction to Qualitative Research Interviewing. Thousand Oaks, CA: Sage Publications.

Kynighou, A. (2014). Variations in corporate influence over HRM between the early and later stages in the life of foreign subsidiaries. The International Journal of Human Resource Management, 25(1), 113-132.

Lee, C. K. (2009). Raw encounters: Chinese managers, African workers and the politics of casualization in Africa's Chinese enclaves. The China Quarterly, 199, 647-666.

Leppäaho, T., Plakoyiannaki, E., \& Dimitratos, P. (2016). The case study in family business: An analysis of current research practices and recommendations. Family Business Review, 0894486515614157. 
Mamman, A., Baydoun, N., \& Adeoye, B. (2009). Transferability of management innovation to Africa: A study of two multinational companies' performance management system in Nigeria. Global Business Review, 10(1), 1-31.

Michailova, S., Mustaffa, Z., \& Barner-Rasmussen, W. (2016). Subsidiaries of multinational corporations: A framework for analysing employee allegiances. Journal of Leadership and Organizational Studies, 23(2), 116-127.

Michalopoulos, S., \& Papaioannou, E. (2013). Precolonial ethnic institutions and contemporary African development. Econometrica, 81(1), 113-152.

Miles, M.B. \& Huberman, A.M. (1994). Qualitative Data Analysis: An Expanded Sourcebook, Sage Publications, Newbury Park, CA.

Mudambi, R., \& Navarra, P. (2002). Institutions and international business: a theoretical overview. International Business Review, 11(6), 635-646.

Nyuur, R. B., Osabutey, E. L., \& Debrah, Y. A. (2014). Doing business in Africa. In The Routledge Companion to Business in Africa, Nwankwo S, and Ibeh K (eds). Routledge: Abingdon, Oxon, UK; 197-204.

Oppong, N. Y., \& Gold, J. (2016). Developing local managers in the Ghanaian mining industry: an indigenous talent model. Journal of Management Development, 35(3), 341-359.

Osabutey, E. L., \& Debrah, Y. A. (2012). Foreign direct investment and technology transfer policies in Africa: A review of the Ghanaian experience. Thunderbird International Business Review, 54(4), 441-456.

Osabutey, E. L., \& Nyuur, R. B., \& Debrah, Y. A. (2015). Developing strategic international human resource capabilities in Sub-Saharan Africa. In International Human Resources Management, Machado C (ed). Springer International Publishing: Switzerland; 37-51.

Osabutey, E. L., Williams, K., \& Debrah, Y. A. (2014). The potential for technology and knowledge transfers between foreign and local firms: A study of the construction industry in Ghana. Journal of World Business 49(4): 560-571.

Osei-Boateng, C., \& E. Ampratwum, E. (2011). The Informal Sector in Ghana. Ghana: Friedrich Ebert Stiftung. http://library.fes.de/pdffiles/bueros/ghana/10496.pdf. Accessed 19th November, 2015.

Petriglieri, J. L. (2015). Co-creating relationship repair pathways to reconstructing destabilized organizational identification. Administrative Science Quarterly, 60(3), 518-557.

Ritchie, J., Lewis, J., Nicholls, C. M., \& Ormston, R. (2014). Qualitative Research Practice: A Guide for Social Science Students and Researchers. London: Sage.

Rosenzweig, P. M., \& Nohria, N. (1994). Influences on human resource management practices in multinational corporations. Journal of international business studies, 25(2), 229-251. 
Sautman, B., \& Yan, H. (2007). Friends and interests: China's distinctive links with Africa. African Studies Review, 50(3), 75-114.

Siebers, L. Q., Kamoche, K., \& Li, F. (2015). Transferring management practices to China: a Bourdieusian critique of ethnocentricity. The International Journal of Human Resource Management, 26(5), 551-573.

Tayeb, M. H. (2005). International Human Resource Management: A Multinational Company Perspective. Oxford University Press.

Tempel, A., \& Walgenbach, P. (2007). Global standardisation of organisational forms and management practices? What new institutionalism and the business-systems approach can learn from each other. Journal of Management Studies, 44(1), 1-24.

Wood, G. (2015). South African multinationals in Africa: Growth and controversy. In Demirbag, M. \& Yeprak, A. (Eds.), Handbook of emerging market multinational corporations. Cheltenham:Edward Elgar.

Xu, D., Pan, Y., \& Beamish, P. W. (2004). The effect of regulative and normative distances on MNE ownership and expatriate strategies (1).Management International Review, 44(3), 285-308.

Yahiaoui, D. (2015). Hybridisation: striking a balance between adoption and adaptation of human resource management practices in French multinational corporations and their Tunisian subsidiaries. The International Journal of Human Resource Management, 26(13), 1665-1693.

York, J. G., Hargrave, T. J., \& Pacheco, D. F. (2016). Converging winds: Logic hybridization in the Colorado wind energy field. Academy of Management Journal, 59(2), 579-610.

Zhao, Z., Anand, J., \& Mitchell, W. (2005). A dual networks perspective on inter-organizational transfer of R\&D capabilities: international joint ventures in the Chinese automotive industry. Journal of Management Studies, 42(1), 127160.

Zoogah, D.B., Peng, M.W., \& Woldu, H. (2015). Institutions, resources, and organizational effectiveness in Africa. Academy of Management Perspectives, $29(1), 7-31$. 